\title{
Assesment of the Genotoxic Effect of the Diazinon on Root Cells of Allium cepa (L.)
}

\author{
Dilek Pandir ${ }^{1 *}$.

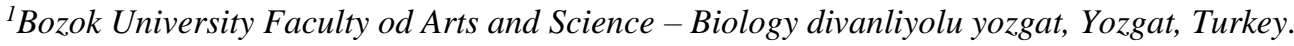

\begin{abstract}
Organophosphorous pesticides (OPs) posses a great potential of acute toxicity for exposed animals and men. To evaluate the toxic potential of the organophosphate diazinon on root meristematic cells of Allium cepa L., was created two groups: In group 1 (control group), was not given any chemical. In group 2 (diazinon-treatment group), different doses (10, 40, 80 and $160 \mathrm{ppm})$ and times periods (24, 48 and $72 \mathrm{~h})$ were administered. After exposure, cell death, effective concentration $\left(E C_{50}\right)$, mitotic index, cellular /chromosome aberrations, DNA damage by comet assay and RAPD-PCR were assessed at exposure times. EC 50 value of diazinon was detected approximately 80 ppm. Hyperchromasia, later segragation, micronucleus, pulverised nucleus, nuclear cytoplasmic shrinkage and cell death, cytoplasmic vacuolation were detected in meristem cells as chromosome/celular aberrations for 72 hat 80 ppm. DNA damage was identified using tail DNA\%, tail lengths and tail moment from these cells. Increasing exposure doses of diazinon caused increasing tail DNA\% and tail lengths at $72 \mathrm{~h}$. DNA bands of increasing concentrations treated groups were more distant to compare with the control group according to RAPD-PCR method. Diazinon cause cytotoxic and genotoxic on A. cepa root and could be considered for further toxicological evaluations.
\end{abstract}

Key words: diazinon, Allium test, DNA damage, genotoxicty, RAPD-PCR

\section{INTRODUCTION}

\footnotetext{
*Author for correspondence: durak77@gmail.com
} 
Pandir, D et al.

\section{INTRODUCTION}

Organophosphorus pesticides (OPs), such as diazinon, are one of the most part used in agriculture as pesticides. To control of soil insects and pests, on ornamental plants, and on fruits, vegetables and field crops, it has been used during the past decade. OPs were caused inhibition of acetyl cholinesterase activity in paralysis and death insects, disorder of nervous system of humans and animals. Previous studies have shown that OPs are mutagenic, carcinogenic, cytotoxic, genotoxic, teratogenic, and immunotoxic ${ }^{1}$.

Diazinon(O,O-diethyl-O-[6-methyl-2-(1-methylethyl)-4-pyrimidinyl]phosphorothioate) $\left(\mathrm{C}_{12} \mathrm{H}_{21} \mathrm{~N}_{2} \mathrm{O}_{3} \mathrm{PS}\right)$ is widely used especially in agriculture but one of great environmental toxic compounds can be absorbed by soil and surface waters. Reaching the living diazinon has decomposed to form diazoxon, hydroxydiazoxon and hydroxydiazinon in microsome of cell ${ }^{2}$.

Many scientific researchers have revealed that diazinon caused histopathological, biochemical and physiological alterations ${ }^{3}$. Diazinon have toxic effects on blood cells, spleen, thymus and lymph nodes of rats $^{4}$ and other organisms ${ }^{5}$. Mitochondrial membrane of rat liver and cytochrome P450 system of human liver were damaged by diazinon $^{6}$. Diazinon caused changes in liver enzymes and biochemical indices and swelling of mitochondria and levels of several enzymes of glucose metabolism in hepatocytes ${ }^{7,8}$. Al-Attar ${ }^{3}$ showed that diazinon causes several severe the hematobiochemical and histopathological alterations in liver, kidney and testis in rats. The Allium cepa (L.) root chromosomal aberration assay, introduced by Levan ${ }^{9}$, is used to detect toxicity of pesticides ${ }^{10}$, herbicides ${ }^{11}$, and other xenobiotics. It is a simple and reliable assay used to record all chromosomal aberrations in mitotic cells ${ }^{12,13}$. The test can be employed to measure both cytotoxicity and genotoxicity; the rate of root growth can be correlated with the mitotic index ${ }^{14}$. Bianchi et al. ${ }^{15}$ evaluated imidacloprid insecticide, sulfentrazone herbicide and to the mixture of them the cytotoxic and genotoxic effects of low concentrations of pesticides on A. cepa for 24 h. Kumar et al. ${ }^{16}$ evaluated the cytogenetic effects of chromium (III) oxide nanoparticles on the root cells of A. cepa. Prajitha and Thoppil ${ }^{17}$ found that possible genotoxic effects of $A$. spinosus leaf extracts on A. cepa root meristematic cells and its antigenotoxic effects against $\mathrm{H}_{2} \mathrm{O}_{2}$-induced genetic damage in A. cepa.

Polymerase chain reaction (PCR) is fundamental to generate a sufficient number of molecular markers with smaller amounts of less pure DNA ${ }^{18}$. The random amplified polymorphic DNA (RAPD) technique determines the DNA sequence for the targeted genome of different vegetables and animal varieties species specific DNA comparison and to evaluate the interaction of toxic material with DNA resulting in damage ${ }^{19}$. Many researchers were used RAPD molecular analysis for determining toxic effect of many chemicals on studies about animal foods and plant ${ }^{18}$. Aksakal et al. ${ }^{20}$ were used the herbicide on root of maize with RAPD assay because of its genotoxic property. Tedeschi et al. ${ }^{18}$ shown that systematic studies could contain RAPD analyses to obtaining characteritic properties of Tropea red onion.

Numerous xenobiotics and some of these free radicals have been given for DNA cell damage. This damage is caused by the disruption of the structure of DNA. It can be measured with comet assay also called Single Cell Gel Electrophoresis (comet) assay. This method is a so fast and sensitive for showing harmful effect of chemicals on DNA of alive cells ${ }^{21}$. This damage can turn into cancer or chromosomal deformity that cause to sister chromatid exchanges, micronuclei, cell death and mutations ${ }^{22}$.

The toxic effects of insecticides, especially diazinon, on A.cepa have not been studied until now. In this study, it was used for the first time six parameters, concentrations of $\mathrm{EC}_{50}$, chromosome/cellular aberrations, cell death, DNA damage, mitotic index and RAPD-PCR in A. серa with diazinon-treatment. Each of the selected parameters 
showed a toxic effect on tissue from a different angle. So, this work was intend to investigate the cytologic, genotoxic and mutagenic changes induced by diazinon effect in this species' roots.

\section{MATERIAL AND METHODS}

\section{Chemicals}

Diazinon, purity 99\%, was obtained from Agricultural Struggle Center, Ankara, Turkey. Oninons (A. cepa $\mathrm{L}$., $2 \mathrm{n}=6$ ) were obtained from a market for Allium test. Used other chemicals in experiment were purchased from Sigma-Aldrich.

\section{Determination of $\mathbf{E C}_{50}$ with Inhibition Test}

The onions (Allium cepa, $2 \mathrm{n}=16$ ) were determined according to whether they received the chemicals.

They were transferred to test tubes containing pure water for $24 \mathrm{~h}$. The root growth inhibition was determinated via this method $(\%$ inhibition $=$ changing in growth/Total growth $\mathrm{X} 100)^{23}$. After one day, the $\mathrm{EC}_{50}$ values of diazinon were determined at room temparature with different concentrations. After treatment period for 4 day, ten roots were obtained from each onion and took from measuring on them. $\mathrm{EC}_{50}$ concentration was determined as one of concentration decreased the root growth by about $50 \%$ compared with the control group. $40 \mathrm{ppm}\left(1 / 2 \mathrm{x}_{50}\right), 80 \mathrm{ppm}\left(\mathrm{EC}_{50}\right)$ and $160 \mathrm{ppm}$ $\left(2 \mathrm{x} \mathrm{EC}_{50}\right)$ concentrations of diazinon were determined and peformed for the Allium test.

\section{Determination of Cytogenetic Effect and Mitotic Index (MI)}

$1 / 2 \mathrm{xEC}_{50}, \mathrm{EC}_{50}$ and $2 \mathrm{x} \mathrm{EC}_{50}$ of concentrations were added into test tubes for 24, 48 and $72 \mathrm{~h}$ when six onion bulbs germinate for $24 \mathrm{~h}$. Tip of roots were collected from control and treatment groups at the high level of maximum mitotic activity on sunny days and used Carnoy's fixative in ethanol: glacial acetic acid (3:1) for $24 \mathrm{~h} .1 \mathrm{~N} \mathrm{HCL}$ was used for hydrolyses at $60{ }^{\circ} \mathrm{C}$ for $7 \mathrm{mins}^{23}$.

After acetocarmine staining for cytogenetic analysis and destaining with $45 \%$ acetic acid, total and damaged cells were detected on six different slides with 40x of light microscope (Olympus BX53 DP72, Japan) .

Mitotic index (MI) was calculated on 5,000 cells for five slides for determining concentrations and applied followed formula for $\mathrm{MI} \%$. MI\% = Divided cell number/Total cell number X 100 formulation ${ }^{23}$.

\section{Determination of Cell Death In Situ Conditions}

Cell death was determined from equal $10 \mathrm{~mm}$ length roots of control and treatment groups using $3 \mathrm{ml}$ of $\mathrm{N}, \mathrm{N}$-dimethylformamide for $1 \mathrm{~h}$ at room temperature. Evans blue was prepared $0.25 \%(\mathrm{w} / \mathrm{v})$ aqueous solution and used for $15 \mathrm{~min}$ and roots were washed with tap water half hour, according to the Baker and Mock ${ }^{24}$. Dead and alive cells were determined according to the characteristics of holding the paint. photos were taken to show their vitality.

\section{Determination of DNA Damage with Comet Assay}

Growing ten onion roots were cut and finely chopped with the help of lancet at the end of $72 \mathrm{~h}$. Roots centrifuged with magnetic stirrer at $500 \mathrm{rpm}$ for $5 \mathrm{~min}$ and then rested for $20 \mathrm{~min}$ in PBS. Low melting point agarose $(0.65 \%)$ was mixed with supernatant of treatment and control groups and then $75 \mu \mathrm{l}$ of suspension was immediately 
transferred on slides which have normal melting point agarose $(0.05 \%)$. The slides were keep at $+4{ }^{\circ} \mathrm{C}$ for $30 \mathrm{~min}$. Slides leaving from coverslip were immersed into cold lysing solution for $1 \mathrm{~h}$. Lysing solutions have $2.5 \mathrm{M} \mathrm{NaCl}, 100 \mathrm{mM}$ EDTA, $10 \mathrm{mM}$ Tris, $\mathrm{pH} 10$, in which $10 \%$ DMSO, $1 \%$ Triton X-100. Horizontal gel electrophoresis platform was filled with freshly made $\mathrm{pH}>13$ electrophoresis buffer $(300 \mathrm{mM} \mathrm{NaOH}$, $1 \mathrm{mM}$ EDTA) until the liquid level completely covers the slides. To unwinding of the DNA, slides were waited for $20 \mathrm{~min}^{25}$. Turn on power supply to $25 \mathrm{~V}$ for $20 \mathrm{~min}$. The slides were lifted gently from the buffer and placed on a drain tray and then washed three times for $5 \mathrm{~min}$ with neutralizing buffer ( $0.4 \mathrm{M}$ Tris-HCl buffer, $\mathrm{pH}$ 7.5). Slides was stained with $80 \mu 1$ of ethidium bromide ( $10 \mathrm{mg}$ in $50 \mathrm{ml}$ of distilled water) for 5 min and then dipped in chilled distilled water to remove excess stain. The slides were covered with coverslip and analysed immediately using BS 200 ProP with software image (BS 200 ProP, BAB Imaging System, Ankara, Turkey). DNA damage was showed a 40x objective on a fluorescent microscope. The tail DNA\% (100 Head\%DNA), tail length and tail moment of 50 comets were identified and calculated differences between groups.

\section{DNA Extraction}

Qiagen DNeasy plant mini kit (Qiagen, Hilden, Germany) was used for the genomic DNA extraction after diazinon treatment for $72 \mathrm{~h}$. All stages was made according to the procedure given by the producer firm.

The optical density (OD) measurements were carried out for sampled DNA at $260 \mathrm{~nm}$ and $280 \mathrm{~nm}$ with a spectrophotometer (ACTGene Micro-Spectrophotometer) and OD260/OD280 was used for the purity of DNA. The A260/A280 ratio demonstrate the DNA purity, 1.8-2.0 values suggest "pure DNA" ${ }^{26}$.

\section{RAPD-PCR}

RAPD-PCR protocol and genomic DNA extraction from control and treatment-groups of diazinon was done with respect to Per and $\operatorname{Ercan}^{26} .2 \mu 1$ of DNA template were used with $0.5 \mu$ dNTPs (10 mM stock solution), $1.5 \mu 1$ PCR buffer [10X buffer with (NH4) SO4, Fermentas), $2 \mu \mathrm{l}$ random primer $\left(10 \mu \mathrm{M}\right.$, Opc5; Sequence $5{ }^{\prime} \rightarrow 3^{\prime}$ GATGACCGCC according to Tedeschi ${ }^{18}$ ), $1.5 \mu \mathrm{MgCl}_{2}(25 \mathrm{mM}$ stock solution, Fermentas), $0.25 \mu \mathrm{l}$ Taq Polymerase ( $5 \mathrm{u} / \mu \mathrm{l}$, Fermentas), $6.05 \mu \mathrm{l}$ of sterile distilled water and $1.2 \mu \mathrm{lBSA}(10 \mathrm{mg} / \mathrm{ml})$. PCR conditions were chosen as one cycle at $94{ }^{\circ} \mathrm{C}$ for $2.5 \mathrm{~min}$, followed by 45 cycles of $45 \mathrm{~s}$ at $94{ }^{\circ} \mathrm{C}, 45 \mathrm{~s}$ at $35^{\circ} \mathrm{C}$ and $45 \mathrm{~s}$ at $72{ }^{\circ} \mathrm{C}$, with a final extension step of $5 \mathrm{~min}$ at $72^{\circ} \mathrm{C}$. Electrophoresis applied with $1 \%$ agarose gel for the PCR products and then done staining with ethidium bromide. Photos of all images were taken.

\section{Statistics}

All results of experiment was compared each other by one-way analysis of variance (ANOVA) with Tukey test. Mean values were given as Standard deviation (SD). $\mathrm{p}<$ 0.05 was used for showing significant.

\section{RESULTS}

Cytotoxic effect of diazinon was showed with Allium test system on commercial onion bulbs. The effects of diazinon appeared at the end of 72 hours. Results of all treatment groups showed that $80 \mathrm{ppm}$ concentration of diazinon was affected decreasing the root length by about $50 \%$, versus the treatment of DMSO (1\%) group. Increasing doses of diazinon have been shown to reduce root growth of bulbs. There were statistically 
significant differences between the groups in root growth receiving 10, 40, 80 and 160 ppm of diazinon $(\mathrm{p}<0.05)($ Table 1$)$.

Table 1- Root growth inhibition test treated with increasing doses of diazinon

\begin{tabular}{ccccc}
\hline Test materials & Concentrations $(\mathrm{ppm})$ & Time & Mean of root length $(\mathrm{cm}) \pm$ & $\%$ inhibition \\
& & & SD & - \\
DMSO (1\%) & - & $96 \mathrm{~h}$ & $4.70 \pm 0.32$ & 14.7 \\
Diazinon & 10 & $4.01 \pm 0.02$ & 33.83 \\
& 40 & $3.11 \pm 0.12^{*}$ & 49.08 \\
& 80 & $2.36 \pm 0.45^{*}$ & 56.59 \\
\hline
\end{tabular}

Asteriks indicate significant differences among exposed to different concentrations of used diazinon in A. cepa cell. Significance at $\mathrm{p}<0.05$.

Evans blue was used for viability testing due to its spread in dead cells. Control and diazinon treatment groups were separated with this process in this study according to Panda et al. ${ }^{27}$. The dye was applied to the roots for a few minutes and the density in the roots was determined. Non-alive cell take up evans blue staining deeply but alive cell don't take up stain intensity (Figure 1). Dyed colors explained the proportional of cell death in the treatment and control groups.
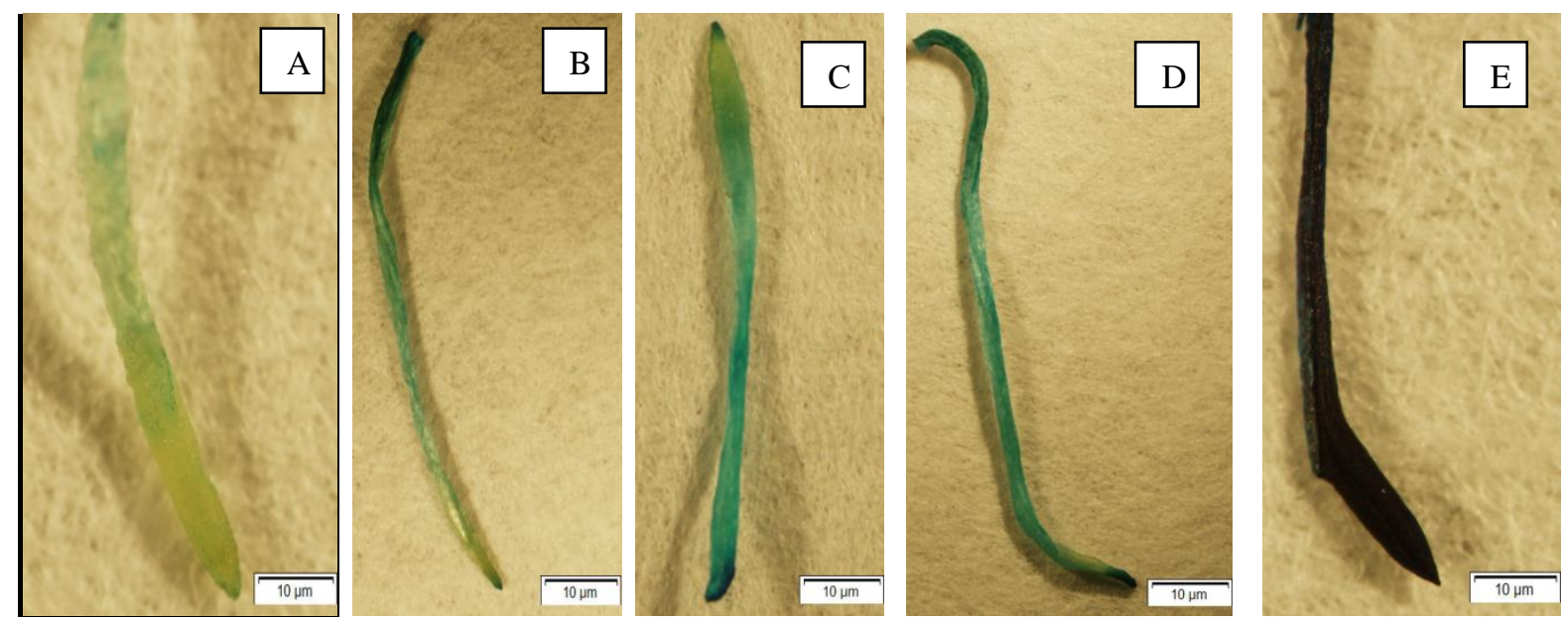

Figure 1. Histochemical staining of cell death of A. cepa roots control and treated with increasing doses of diazinon (A) control group, (B) 10 ppm, (C) 40 ppm, (D) 80 ppm, (E) 160 ppm of diazinon.

Choromosome anomalies were showed as hyperchromasia, later segragation, micronucleus, chromosome loss, chromosomal adherence, chromatin globules, pulverised nucleus in anaphase-telophase phase for $72 \mathrm{~h}$ treatment groups compared to control cells (Figures $2 \mathrm{~A}-\mathrm{H}$ ). While $13.5 \%$ anomalies were obtained at the $10 \mathrm{ppm}$ of diazinon at $24 \mathrm{~h}, 99.9 \%$ anomalies were observed at the $160 \mathrm{ppm}$ at $72 \mathrm{~h}$ (Table 2). Cytoloplasmic changing were obtained from roots of A. cepa such as cell fragmentation and receding of cell contents, nuclear cytoplasmic shrinkage and cell death, cytoplasmic vacuolation, cellular breakage (Figures 2I-L). 

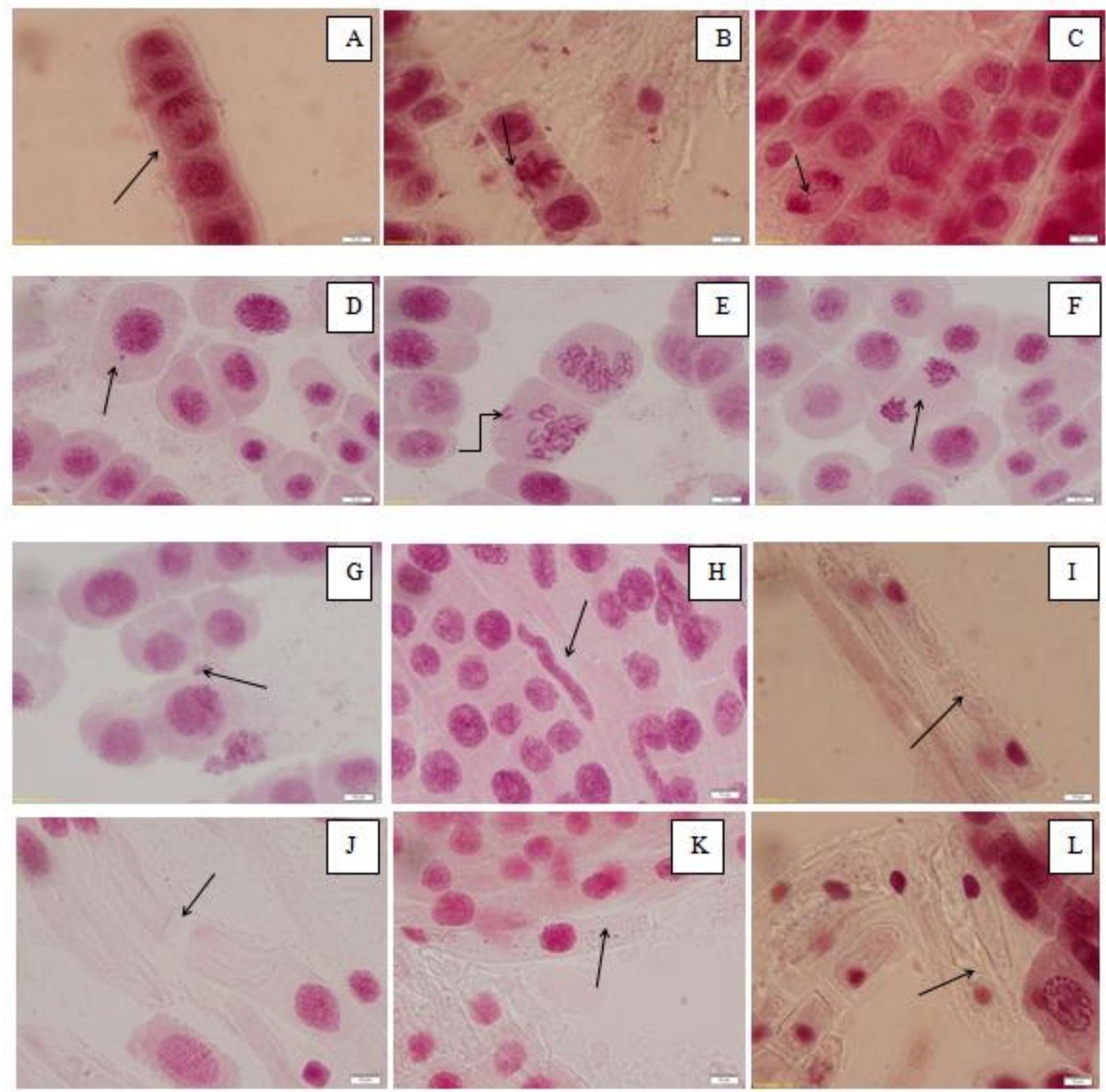

Figure 2. Chromosome and celular abnormalities. Bars $=10 \mu \mathrm{m}(\mathrm{A})$ normal anaphase, $(\mathrm{B})$ hyperchromasia, $(\mathrm{C})$ later segragation, (D) micronucleus, (E) chromosome loss, (F) chromosomal adherence, (G) chromatin globules, (H) pulverised nucleus, (I) cell fragmentation and receding of cell contents, $(\mathrm{J})$ nuclear cytoplasmic shrinkage and cell death, (K) cytoplasmic vacuolation, (L) cellular breakage. 
Effect of diazinon on Allium cepa root cells

Table 2. Percentage of chromosome aberrations of diazinon at differrent doses and times

SD: standard deviation

*Significantly different from control $(\mathrm{p}<0.05)$

\begin{tabular}{|c|c|c|c|c|c|c|c|c|c|c|c|}
\hline $\begin{array}{l}\text { Concentration } \\
(\mathrm{ppm})\end{array}$ & $\begin{array}{l}\text { Counted } \\
\text { cell }\end{array}$ & $\begin{array}{l}\text { Mitotic } \\
\text { index } \% \pm S D\end{array}$ & $\begin{array}{c}\text { hyperchr } \\
\text { omasia }\end{array}$ & $\begin{array}{c}\text { later } \\
\text { segraga } \\
\text { tion }\end{array}$ & $\begin{array}{c}\text { micro } \\
\text { nucle } \\
\text { us }\end{array}$ & $\begin{array}{c}\mathrm{c}- \\
\text { mitosis }\end{array}$ & $\begin{array}{c}\text { chro } \\
\text { moso } \\
\text { me } \\
\text { loss }\end{array}$ & $\begin{array}{c}\text { chro } \\
\text { moso } \\
\text { mal } \\
\text { adher } \\
\text { ence }\end{array}$ & $\begin{array}{l}\text { chroma } \\
\text { tin } \\
\text { globule } \\
\mathrm{s}\end{array}$ & $\begin{array}{l}\text { pulverise } \\
\text { d nucleus }\end{array}$ & $\begin{array}{c}\text { Total } \\
\text { anomalie } \\
\mathrm{s} \\
(\%) \pm \mathrm{SD}\end{array}$ \\
\hline Control-24 & 4515 & $12.23 \pm 2.98$ & - & - & - & - & - & - & - & 1 & 1 \\
\hline $10 \mathrm{ppm}$ & 4523 & $12.65 \pm 3.65$ & 3.4 & 0.1 & - & 2.8 & 1 & 1 & 0.2 & 5 & 13.5 \\
\hline $40 \mathrm{ppm}$ & 4525 & $12.45 \pm 2.81$ & 5.3 & 0.1 & 0.1 & 4 & 3 & 5 & 0.4 & $10^{*}$ & 27.9 \\
\hline $80 \mathrm{ppm}$ & 4522 & $10.54 \pm 1.45 *$ & $18.2^{*}$ & $0.4^{*}$ & 0.3 & $15.2 *$ & 5 & $9 *$ & 0.6 & $12 *$ & 60.5 \\
\hline $160 \mathrm{ppm}$ & 4532 & $10.05 \pm 1.42 *$ & $25.4^{*}$ & $0.5^{*}$ & $0.5^{*}$ & $19.2 *$ & $7 *$ & $13 *$ & $1 *$ & $18^{*}$ & 84.6 \\
\hline Control-48 & 4188 & $12.85 \pm 2.45$ & 1.2 & - & - & 2 & 1 & 1 & 0.1 & 3 & 8.3 \\
\hline $10 \mathrm{ppm}$ & 4370 & $10.20 \pm 1.17$ & 7.2 & 0.8 & 0.1 & 5.4 & 2 & 6 & 0.3 & 8 & 29.8 \\
\hline $40 \mathrm{ppm}$ & 4315 & $9.85 \pm 3.45^{*}$ & $11.3^{*}$ & 0.9 & 0.2 & $10.2 *$ & $5^{*}$ & $12 *$ & 0.5 & $15^{*}$ & 55.1 \\
\hline $80 \mathrm{ppm}$ & 4550 & $8.65 \pm 1.85^{*}$ & $22.4^{*}$ & $1.1^{*}$ & 0.3 & $20.1 *$ & $6^{*}$ & $15^{*}$ & $0.9 *$ & $19 *$ & 84.8 \\
\hline $160 \mathrm{ppm}$ & 4387 & $7.80 \pm 2.45^{*}$ & $26.5^{*}$ & $1.6^{*}$ & $0.6^{*}$ & $21.2 *$ & $6^{*}$ & $18^{*}$ & $1.3^{*}$ & $15^{*}$ & 90.2 \\
\hline Control-72 & 4218 & $12.35 \pm 2.14$ & 3.5 & - & - & 1 & - & 2 & 1 & 5 & 12.5 \\
\hline $10 \mathrm{ppm}$ & 4451 & $12.4 \pm 3.20$ & 12 & 1.5 & - & 7.2 & 1 & 7 & 3 & $14^{*}$ & 45.7 \\
\hline $40 \mathrm{ppm}$ & 4280 & $9.55 \pm 1.40^{*}$ & $16.2 *$ & 1.5 & 0.4 & $11.4^{*}$ & 4 & $10^{*}$ & 5 & $19 *$ & 67.5 \\
\hline $80 \mathrm{ppm}$ & 4270 & $8.20 \pm 1.25^{*}$ & $25.8 *$ & 1.7 & $0.6^{*}$ & $18.2 *$ & 5* & $13^{*}$ & $6^{*}$ & $25^{*}$ & 98 \\
\hline $160 \mathrm{ppm}$ & 4280 & $5.25 \pm 0.45^{*}$ & $27 *$ & $1.9^{*}$ & $0.8^{*}$ & $19.2 *$ & $6^{*}$ & $14^{*}$ & $6^{*}$ & $27 *$ & 99.9 \\
\hline
\end{tabular}

Level of MI of root meristem cell of roots were showed in diazinon treatment group and control groups (Table 2). There were statistically significant differences between the groups in MI (\%) receiving 10, 40, 80 and $160 \mathrm{ppm}$ of diazinon at each exposure time versus to control. The lowest MI\% values were obtained from $72 \mathrm{~h}$ applications of $160 \mathrm{ppm}$ with a score of $5.25 \pm 0.45$

Table 3 and Figure 3 showed the tail DNA\%, tail length and tail moments in meristem cells of A. cepa root subjected to diazinon $72 \mathrm{~h}$. Evaluated were significantly $(\mathrm{p}<0.05)$ increased in diazinon treatment with increasing the treatment concentrations $(10,40$, 80 and $160 \mathrm{ppm}$ ). The $\%$ tail DNA values ranged from $65.70 \pm 2.18$ to $92.55 \pm 2.78$ and tail length values ranged from $26.00 \pm 40.24$ to $60.00 \pm 16.97$ (Figures 3A-E). There is no statistically significance between treatment groups in DNA damage in control and $10 \mathrm{ppm}$ of diazinon compared with 80 and $160 \mathrm{ppm}$ of diazinon $(\mathrm{p}<0.05)$.

Table 3. Scored DNA damage $( \pm \mathrm{SD})$ in cells from A. cepa roots exposure to increasing concentrations with mean values of tail DNA\%, tail length and tail moment of comets by image analysis

\begin{tabular}{|c|c|c|c|}
\hline Different exposure concentrations of diazinon & $\begin{array}{c}\text { Tail DNA\% } \\
\text { Mean } \pm \text { SD }\end{array}$ & $\begin{array}{c}\text { Tail length } \\
\text { Mean } \pm \text { SD }\end{array}$ & $\begin{array}{c}\text { Tail moment } \\
\text { Mean } \pm \text { SD }\end{array}$ \\
\hline Control & $65.70 \pm 2.18^{\mathrm{a}}$ & $26.00 \pm 4024^{\mathrm{a}}$ & $17.27 \pm 3.36^{\mathrm{a}}$ \\
\hline $10 \mathrm{ppm}$ & $66.63 \pm 2.00^{\mathrm{a}}$ & $27.50 \pm 5.30^{\mathrm{a}}$ & $18.54 \pm 4.08^{\mathrm{a}}$ \\
\hline $40 \mathrm{ppm}$ & $88.78 \pm 2.45^{\mathrm{b}}$ & $45.50 \pm 1.06^{\mathrm{b}}$ & $40.37 \pm 0.24^{\mathrm{b}}$ \\
\hline $80 \mathrm{ppm}$ & $92.06 \pm 2.28^{\mathrm{c}}$ & $57.00 \pm 14.14^{\mathrm{c}}$ & $53.12 \pm 14.32^{\mathrm{c}}$ \\
\hline $160 \mathrm{ppm}$ & $92.55 \pm 2.78^{\mathrm{c}}$ & $60.00 \pm 16.97^{\mathrm{c}}$ & $56.47 \pm 17.37^{\mathrm{c}}$ \\
\hline
\end{tabular}


Superscript letters indicate significant differences among exposed to different concentrations of diazinon on roots cell. Significance at $\mathrm{p}<0.05$.
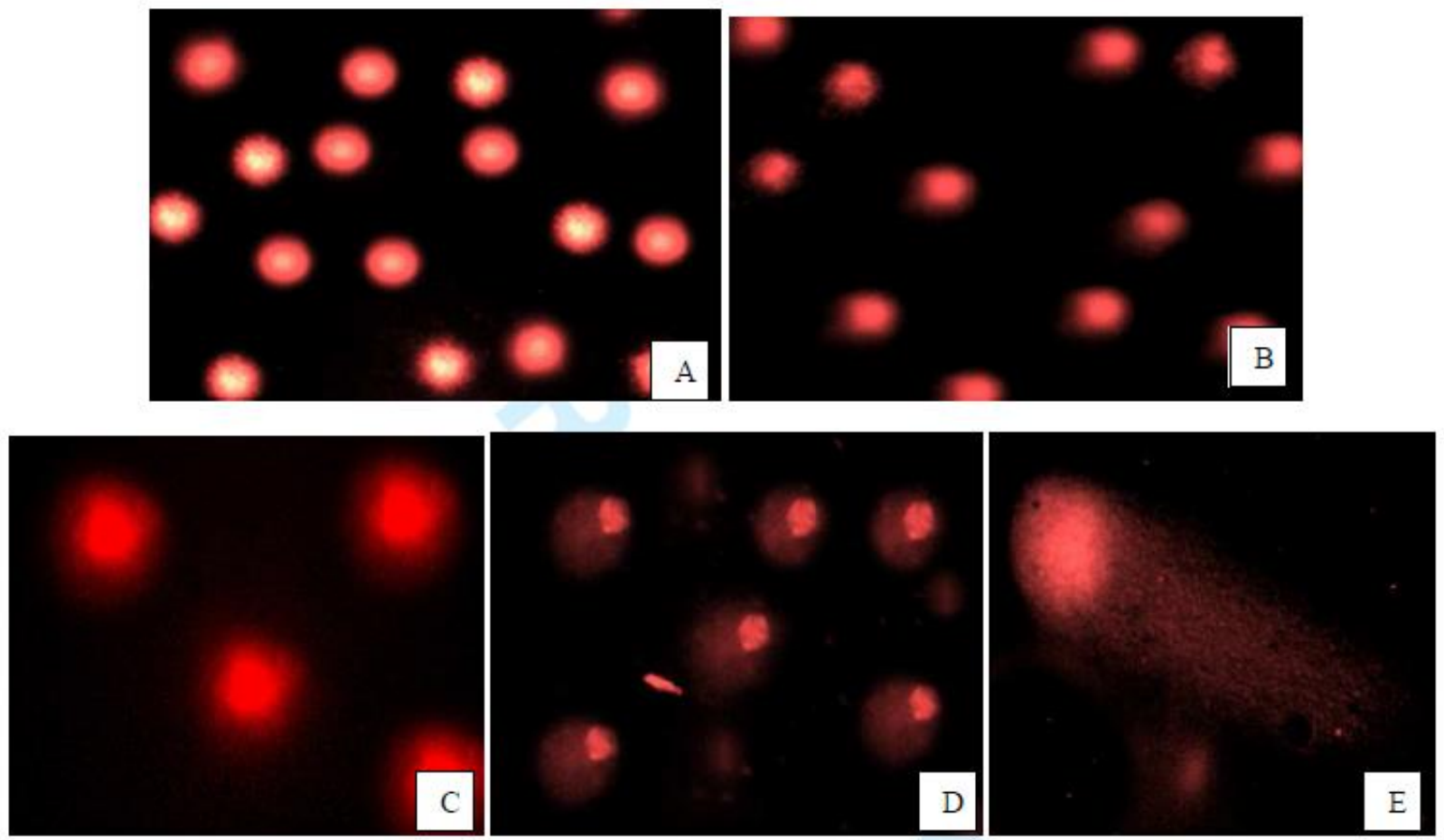

Figure 3. Comet assay micrograph of root tissues of $A$. cepa treated with increasing doses of diazinon for $72 \mathrm{~h}$. (A) control (B) 10 ppm, (C) 40 ppm, (D) 80 ppm (E) 160 ppm.

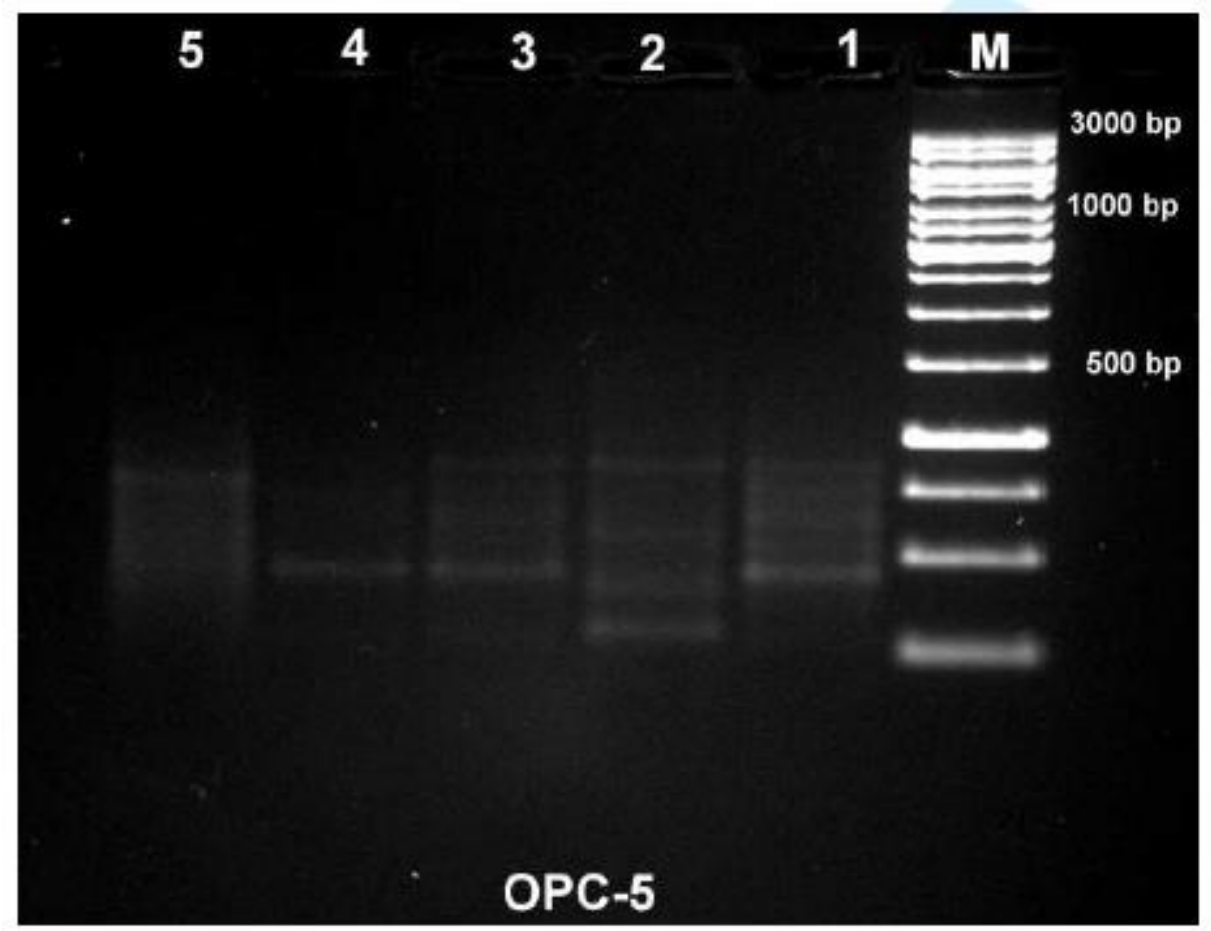

Figure 4. OPC-5 RAPD primers used in (1) control group, and diazinon treatment groups (2) 10 ppm, (3) 40 ppm, (4) $80 \mathrm{ppm}$, (5) $160 \mathrm{ppm}$ for $72 \mathrm{~h}$.

Extraction and purification of DNA were obtained from A. cepa roots and 260 and $280 \mathrm{~nm}$ of optical density (OD) was obtained between 1.8-2.0. It means that DNA is quite free of 
Effect of diazinon on Allium cepa root cells

protein ${ }^{28}$. Figure 4 seen toxic effect of different concentrations of diazinon on the structures of RAPD profiles of bulbs. Appearance of new bands or/and disappearance of normal bands were obtained from increasing concentrations of the diazinon compared with the control samples.

\section{DISCUSSION}

Effect of OPs insecticides were determined in terms of human health. Previous study demonstrated that there is important increase in accumulate and damage to non-target species $^{29}$. Diazinon is also an OP which provide controlling insects in crops, ornamentals, lawns, fruit and vegetables and as a pesticide in domestic and agricultural 30. In this study, several effects were observed in the A. cepa cells analyzed in accordance with the concentrations magnitude of diazinon. Concentration of $\mathrm{EC}_{50}$ is important parameter for determining the toxic effect. It was obtained $\mathrm{EC}_{50}(80 \mathrm{ppm})$, $2 \mathrm{xEC}_{50}(160)$ and $1 / 2 \mathrm{x} \mathrm{EC}_{50}(40 \mathrm{ppm})$ value according to length of each root for diazinon. To show the posibble harmful effects on tips, determined concentrations of diazinon were used in this study.

Diazinon causing cytoxic and genotoxic effect has not been used on A. cepa roots until now. To determinate of these effects of chemicals, Allium test system is used because of sensitive and best system ${ }^{27,31}$. Also, A. cepa has a great deal of correlation with many cells ${ }^{23}, 32$. In this study, diazinon was showed that it has toxic effect on alive cells. Especially, diazinon determined toxic effect on A. cepa meristematic cell, root growth and also possibly lead to DNA damage.

Bhagyanathan and Thoppil ${ }^{33}$ were used Cynanchum sarcomedium for determining viable and non-viable cells of $A$. cepa roots. Non-alive cells of this plant stained with different level according to treatment period. Different level of plant extract showed high cell death and this sutiation is similiar method of evans blue staining. In this work, diazinon caused to highly toxic effect and because of showing strong and weak staining in root tips. Obtained roots from six bulbs were used for defining of death of cells. The root color was found to be at a very high density after 72 hours.

Previous studies have been showed mitotic index of roots' meristematic cells of $A$. cepa affected by some pesticides. Bianchi et al. ${ }^{34}$ demonstrated that insecticide imidacloprid did not induce visible chromosomal changes in meristematic and F1 cells of $A$. cepa when exposed for $24 \mathrm{~h}$ but herbicide sulfentrazone caused a cytotoxic effect which could be visualized by total inhibition of cell division and nuclear fragmentation. Rodríguez et al. ${ }^{35}$ showed the toxicity of imidacloprid on the DNA of A. cepa roots with exposure to different concentrations of this insecticide, demonstrating that chromosomal alterations and frequency of micronuclei increased in the tested concentrations of imidacloprid. Therefore, imidacloprid was genotoxic to the tested organisms. Few studies have examined its toxicity at the genetic level although diazinon is one of the most widely used worldwide. In this work, changing DNA structure show that increasing doses of diazinon have the possible toxic effect on the chromosomes of $A$. cepa roots cell and also mitotic index (MI) of tips was inhibited increasing doses of diazinon end of 24, 48 and $72 \mathrm{~h}$.

According to Saxena et al. ${ }^{36}$ carbofuran toxicity was showed that chromosomal and mitotic aberrations in the root meristem cells of A. cepa exposed to carbofuran for 24 h. Aqueous extracts of $C$. sarcomedium induced chromosomal aberrations on root of A. cepa $^{33}$. Hyperchromasia, later segragation, micronucleus, c-mitosis, chromosome loss, chromosomal adherence, chromatin globules, pulverised nucleus were determined as chromosomal disruption. According to results, the total chromosomal changing increased with increasing diazinon concentrations and exposure time as compared to the control. In this study, cytological changing were determined intracellular levels. Results presented here confirm the high sensitivity of root with 
significant increases in cell damage after treatment of cell with doses of 24-72 h of increasing doses of diazinon. Major cellular changing were obtained as cytoplasmic shrinkage, cell fragmentation, cell membrane damage, cytoplasmic vacuolation, cellular breakage on root cells. The increasing treatment concentrations and times of diazinon cause statistically significant $(\mathrm{p}<0.05)$ damage in root cells in this study. All these changing result from membrane damage, vacuolar disentegrations and reducing of cell contents.

To detect changing of DNA structure of living cell, comet assay can utulize for determining toxic effect of various chemicals ${ }^{21}$. Genotoxicity of AgNP was detected with comet assay on A. cepa cell for obtaining DNA damage ${ }^{27}$. AgNP significantly caused broken strand of DNA in a dose-dependent manner on the root tips of $A$. cepa ${ }^{37}$. Comet assay showed that DNA damage was significantly higher in 20 and $40 \mathrm{ppm}$ of IM compared to the control. Herbicide has cytotoxic activity but not genotoxic activity (except $10 \mathrm{ppm}$ ) according to dose dependent manner in A. cepa root meristematic cells. In another study, genotoxic effects of chlorfenvinphos and fenbuconazole were used for comet assay on the root meristem cells of A. cepa. Increasing concentrations were used on the roots for 24 and $48 \mathrm{~h}$ and DNA damage was demonstrated in treatments chemical groups compared to the control ${ }^{38}$. In this study, after the exposure period, single strand DNA breaks by comet assay were used. Single strand DNA breaks were measured as tail DNA\%, tail length and tail moment of comet. The effects of diazinon on the roots cells of A.cepa with regard to tail DNA\% and tail length were determined. Its clearly demonstrated, particularly tail DNA\% and tail length increased in treatment group of diazinon for $72 \mathrm{~h}$.

RAPD markers are also used to show DNA damage and mutations ${ }^{20}$. Ozakca and Silah $^{19}$ were shown that toxic effect of fungicide flusilazole on somatic cells of A. cepa using randomly amplified polymorphic DNA method. The RAPD method was used to demonstrate the toxic effect of different doses of diazinon on root tips. Diazinon application induced band loss and changing band density in DNA due to presence of DNA photoproducts and severe DNA inhibition. The genetic differences was obtained in most exposure to $80 \mathrm{ppm}$ and $160 \mathrm{ppm}$ concentrations of diazinon group end of 72 h. In terms of the RAPD method, all the changes in the DNA structure, the disappearance of the bands, the formation of new bands, the changes in the band density have shown that diazinon may be a toxic substance for root tips.

\section{CONCLUSION}

The effects of used insecticide on the A. cepa roots cytogenetic and mutagenic have not previously been described. These results show that the effect of diazinon on roots cell depends on the concentrations and times. Root cells are apparently more sensitive to pesticide and show increased celular and choromosomal disorder, DNA damage after increasing exposure time. Therefore, it would be important to further toxic work and cytological evidences at molecular level to demonstrate the possible toxic effect of diazinon.

\section{ACKNOWLEDGEMENTS}

The author would like to thank to Fatih Oguz BEKDEMIR for helping me to prepare this study 
Effect of diazinon on Allium cepa root cells

\section{REFERENCES}

1. Aronzon CM, Marino DJG, Ronco AE, Perez Coll CS. Differential toxicity and uptake of diazinon on embryo-larval development of Rhinella arenarum. Chemosphere. 2014; 100: $50-56$.

2. WHO, Diazinon, Environmental Health Criteria 198, International Program on Chemical Safety, United Nations Environmental Program. World Health Organization, Geneva, Switzerland 1998.

3. Al-Attar AM. Effect of grapeseed oil on diazinon-induced physiological and histopathological alterations in rats. Saudi J Biol Sci. 2015; 22:.284-292.

4. Handy RD, Abd-El Samei HA, Bayomy MF, Mahran AM, Abdeen AM, El-Elaimy EA. Chronic diazinon exposure: pathologies of spleen, thymus, blood cells, and lymph nodes are modulated by dietary protein or lipid in the mouse. Toxicology. 2002; 172(1): 13-34.

5. Li ZH, Velisek J, Zlabek V, Grabic R, Machova J, Kolarova J. Hepatic antioxidant status and hematological parameters in rainbow trout, Oncorhynchus mykiss, after chronic exposure to carbamazepine. Chem Biol Interact. 2010; 183(1): 98-104.

6. Elsaid FG, Shati AA, Sarhan MA. Role of Matricaria recutita L. and Asparagus officinalis L. against the neurotoxicity of diazinon in rats. J Basic Appl Zool. 2015; 72: 26-35.

7. Kalender S, Ogutcu A, Uzunhisarcikli M. et al. Diazinon-induced hepatotoxicityand protective effect of vitamin $\mathrm{E}$ on some biochemical indices and ultra-structural changes. Toxicology. 2005; 211: 197-206.

8. Seifert J. Changes in mouse liver and chicken embryo yolk sac membrane soluble proteins due to an organophosphorous insecticide (OPI) diazinon linked to several noncholinergic OPI effects in mice and chicken embryos. Pestic Biochem Physiol. 2014; 116: 74-82.

9. Levan A. The effect of colchicines on root mitoses in Allium. Hereditas. 1938; 24: 471486.

10. Mastrangelo S, Tomassetti M, Carratu MR, Evandri MG, Bolle P. Quercetin reduces chromosome aberrations induced by atrazine in the Allium cepa test. Environ Mol Mutagen. 2006; 47: 254-259.

11. Yel M, Arikan ES. Genotoxicity testing of quizalofop-p-ethyl herbicide using Allium сера anaphase-telophase chromosome aberration assay. Caryologia. 2008; 61: 4552.

12. Rank J, Nielsen MH. Allium cepa anaphase telophase root tip chromosome aberration assay on $\mathrm{N}$-methylnitosourea, maleic hydrazide, sodium azide, and ethyl methanesulfonate. Mutat Res. 1997; 390: 121-127.

13. Natarajan AT. Chromosome aberrations: past, present and future. Mutat Res. 2002; 504: 3-16.

14. Liu DH, Jiang WS, Lt MX. Effects of trivalent and hexavalent chromium on root growth and cell division of Allium cepa. Hereditas. 1992; 117. 23-29.

15. Bianchi J, Fernandes TCC, Marin-Morales MA. Induction of mitotic and chromosomal abnormalities on Allium cepa cells by pesticides imidacloprid and sulfentrazone and the mixture of them. Chemosphere. 2016; 144: 475-483.

16. Kumar D, Rajeshwari A, Jadon PS, Chaudhuri G, Mukherjee A, Chandrasekaran $\mathrm{N}$, et al. Cytogenetic studies of chromium (III) oxide nanoparticles on Allium cepa root tip cells. J Env Sci. 2015; 38: 150-157.

17. Prajitha V, Thoppil JE. Genotoxic and antigenotoxic potential of the aqueous leaf extracts of Amaranthus spinosus Linn. using Allium cepa assay. S Afr J Bot. 2016; 102: $18-25$.

18. Tedeschi P, Bonetti G, Maietti A, Brandolini V. Random amplified polymorphic DNA (RAPD) fingerprint and antioxidants profile as markers for Tropea red onion (Allium cepa L.) authenticity. J Food Comp Anal. 2014; 36: 98-103.

19. Ozakca DU, Silah H. Genotoxicity effects of Flusilazole on the somatic cells of Allium cepa. Pestic Biochem Physiol. 2013; 107(1): 38-43.

20. Aksakal O, Erturka FA, Sunar S, Bozari S, Agar G. Assessment of genotoxic effects of 2,4 dichlorophenoxyacetic acid on maize by using RAPD analysis. Ind Crops Prod. 2013; 42: 552-557. 
21. Pandir D. Protective effect of (-)-epigallocatechin-3-gallate on capsaicin-induced DNA damage and oxidative stress in human erythrocytes and leucocytes in vitro. Cytotechnology. 2015; 67(2): 367-377.

22. Hirose H, Sakuma N, Kaji N, Suhara T, Sekijima M, Nojima T. Miyakoshi J. Phosphorylation and gene expression of p53 are not affected in human cells exposed to $2.1425 \mathrm{GHz}$ band $\mathrm{CW}$ or W-CDMA modulated radiation allocated to mobile radio base stations. Bioelectromagnetics. 2006; 27: 494-504.

23. Fiskesjō G. The Allium as a standard in environmental monitoring. Hereditas 1985; 102: 99-102.

24. Baker CJ, Mock NM. An improved method for monitoring cell death in cell suspension and leaf disc assays using Evan's blue. Plant Cell Tissue Organ Cult. 1994; 39: $7-12$.

25. Ozkan D, Yuzbaşıoğlu D, Unal F, Yılmaz S, Aksoy H. Evaluation of the cytogenetic damage induced by the organophosphorous insecticide acephate. Cytotechnology. 2009; 59: 73-80.

26. Per S, Ercan FS. Comparison of three methods of DNA extraction from Parachipteria willmanni (Acari: Oribatida) collected in Turkey. J Biotech Res. 2015; 1(4): 16-20.

27. Panda KK, Achary VMM, Krishnaveni R, Padhi BK, Sarangi SN, Sahu SN, Panda BB. In vitro biosynthesis and genotoxicity bioassay of silver nanoparticles using plants. Toxicol In Vitro. 2011; 25(5): 1097-1105.

28. Tixier MS, Okassa M, Liguori M, Poinso A, Salerno B, Kreiter S. Voucher specimens for DNA sequences of Phytoseiid mites (Acari: Mesostigmata). Acarol. 2010; 50: 487-494.

29. Fleischli MA, Franson JC, Thomas NJ, Finley DL, Riley W. Avian mortality events in the United States caused by anticholinesterase pesticides: a retrospective summary of National Wildlife Health Center records from 1980 to 2000. Arch Environ Contam Toxicol. 2004; 46: 542-550.

30. Garfitt SJ, Jones K, Mason HJ, Cocker J. Exposure to the organophosphate diazinon: data from a human volunteer study with oral and dermal doses. Toxicol Lett. 2002; 134: 105-113.

31. Barberio A, Voltolini JC, Mello MLS. Standardization of bulb and root sample sizes for the Allium cepa test. Ecotoxicol. 2011; 20: 927-935.

32. Yild1z M, Cigerci IH, Konuk M, Fidan AF, Terzi H. Determination of genotoxic effects of copper sulphate and cobalt chloride in Allium cepa root cells by chromosome aberration and comet assays. Chemosphere. 2009; 75: 934.

33. Bhagyanathan NK, Thoppil JE. Pre-apoptotic activity of aqueous extracts of Cynanchum sarcomedium Meve \& Liede on cells of Allium cepa and human erythrocytes. Protoplasma. DOI 10.1007/s00709-015-0898-y.

34. Bianchi J, Fernandes TCC, Marin-Morales MA. Induction of mitotic and chromosomal abnormalities on Allium cepa cells by pesticides imidacloprid and sulfentrazone and the mixture of them. Chemosphere. 2016; 144: 475-483.

35. Rodríguez YA, Christofoletti CA, Pedro J, Bueno OC, Malaspina O, Ferreira RAC, Fontanetti CS. Allium cepa and Tradescantia pallida bioassays to evaluate effects of the insecticide imidacloprid. Chemosphere. 2015; 120: 438-442.

36. Saxena PN, Gupta SK, Murthy RC. Carbofuran induced cytogenetic effects in root meristem cells of Allium cepa and Allium sativum: A spectroscopic approach for chromosome damage. Pestic Biochem Physiol. 2010; 96 (2): 93-100.

37. Liman R, Ciğerci IH, Ozturk NS. Determination of genotoxic effects of Imazethapyr herbicide in Allium cepa root cells by mitotic activity, chromosome aberration, and comet assay. Pestic Biochem Physiol. 2015; 118: 38-42.

38. Turkoglu S. Determination of genotoxic effects of chlorfenvinphos and fenbuconazole in Allium cepa root cells by mitotic activity, chromosome aberration, DNA content, and comet assay. Pestic Biochem Physiol. 2012; 103: 224-230. 
Effect of diazinon on Allium cepa root cells

Received: February 03, 2016; Accepted: July 14, 2016

Braz. Arch. Biol. Technol. v.61: e18160390 2018 